\title{
KEMAMPUAN MENGIDENTIFIKASI UNSUR PEMBANGUN CERITA FANTASI SISWA KELAS VII SMPN 6 KOTA BENGKULU
}

\author{
'Riska Handayani; ${ }^{2}$ Gumono; ${ }^{3}$ M. Arifin \\ 1,2,3 Program Studi Pendidikan Bahasa Indonesia FKIP Universitas Bengkulu
}

Abstrak

\section{Korespondensi: riskalubisikariska97@gmail.com}

Tujuan penelitian ini untuk mengetahui kemampuan mengidentifikasi unsur pembangun cerita fantasi siswa kelas VII SMPN 6 Kota Bengkulu. Metode yang digunakan dalam penelitian ini adalah deskriptif dengan pendekatan kuantitatif. Penelitian ini dilakukan di SMPN 6 Kota Bengkulu. Populasi penelitian ini adalah siswa kelas VII SMPN 6 Kota Bengkulu. Sampel penelitian berjumlah 47 orang siswa dari jumlah populasi. Teknik sampling yang diterapkan adalah purposive sampling. Pengumpulan data yang digunakan adalah teknik analisis data menggunakan persentase dalam mengidentifikasi unsur pembangun cerita fantasi. Hasil penelitian kemampuan mengidentifikasi unsur pembangun cerita fantasi siswa kelas VII SMPN 6 Kota Bengkulu dari keseluruhan aspek memperoleh nilai rata-rata sebesar 67,89 termasuk dalam kategori cukup berada pada rentang nilai 56-69.

Kata Kunci: membaca, mengidentifikasi, cerita fantasi

\begin{abstract}
The purpose of this study was to determine students ability to identify constructive elements of fantasy stories of first grade students of SMPN 6 Kota Bengkulu. The method used in this study was descriptive with a quantitative approach. This research was conducted at SMPN 6 Bengkulu City. The population of this study were seventh grade students of SMPN 6 Bengkulu City. The research sample consisted of 47 students from the population. The sampling technique applied was purposive sampling. Data collection used was data analysis technique using percentages in identifying fantasy story constructive elements. The results of the study was students ability to identify fantasy story constructive elements of first grade students of SMPN 6 Bengkulu City of all aspects obtained an average value 67.89, classified is enough category in the range of values 56-69.
\end{abstract}

Keywords: Reading, Identifying, Fantasy Stories 


\section{PENDAHULUAN}

Pembelajaran Bahasa Indonesia merupakan salah satu pembelajaran wajib pada semua jenjang pendidikan. Mata pelajaran Bahasa Indonesia bertujuan agar siswa memiliki kompetensi berbahasa Indonesia untuk berbagai fungsi komunikasi dalam berbagai kegiatan sosial. Untuk mencapai tujuan ini ada empat aspek keterampilan berbahasa yang harus dikuasai, yaitu menyimak, berbicara, membaca, dan menulis. Dalam Kurikulum 2013 mata pelajaran Bahasa Indonesia menggunakan pendekatan berbasis teks. Pendekatan ini bertujuan agar siswa mampu memproduksi dan menggunakan teks sesuai dengan tujuan dan fungsi sosialnya. Pembelajaran Bahasa Indonesia berbasis teks berfungsi sebagai penghela ilmu pengetahuan. Senada dengan hal tersebut, Mahsun (2014:8) teks merupakan suatu proses sosial yang berorientasi pada suatu tujuan sosial. Pada uraian peneliti menjelaskan bahwa dalam mengidentifikasi suatu teks tidak terlepas dari aspek membaca karena membaca lebih di utamakan serta dapat membantu proses pembelajaran.

Dalman (2013:05) mengatakan membaca merupakan suatu kegiatan atau proses kognitif yang berupaya untuk menemukan berbagai informasi yang terdapat dalam tulisan. Hal ini berarti membaca merupakan proses berpikir untuk memahami isi teks yang dibaca. Oleh sebab itu, membaca bukan hanya sekedar melihat kumpulan huruf yang telah membentuk kata, kelompok kata, kalimat paragraf dan wacana saja, tetapi lebih dari itu membaca merupakan kegiatan memahami dan menginterpretasikan lambang, tanda, tulisan yang bermakna sehingga pesan yang disampaikan penulis dapat diterima oleh pembaca. Kurikulum 2013 terdapat adanya kompetensi dasar 3.3 "Mengidentifikasi unsur-unsur teks narasi (cerita fantasi) yang dibaca dan didengar" dengan indikator kompetensi 3.3.1 menjelaskan ciri tokoh, latar, alur, tema pada cerita fantasi dan menunjukkan buktinya pada teks yang dibaca dan didengar. Berdasarkan revisi Kurikulum 2013 cerita fantasi termasuk salah satu bentuk teks narasi pada mata pelajaran bahasa Indonesia di kelas VII SMP/MTS. Zulela (2013:46) cerita fantasi adalah cerita yang dikembangkan dengan menghadirkan sebuah dunia lain di samping dunia realitas. Cerita fantasi adalah cerita yang menampilkan tokoh, alur, karakter dan lainnya, yang kebenarannya diragukan, baik seluruh cerita maupun sebagian cerita yang menyuguhkan makna lebih dari sekadar yang dikisahkan.

Kemampuan mengidentifikasi unsur pembangun cerita fantasi ini ialah kesanggupan, kecakapan, kekuatan seseorang dalam suatu kegiatan mencari, menemukan, mengumpulkan, meneliti serta mencatat data dan informasi dari kebutuhan pada sebuah teks cerita. Dari hasil observasi diketahui bahwa guru merasakan adanya kesulitan untuk mengajari siswa tentang teks cerita fantasi di SMPN 6 Kota Bengkulu yang baru menerapkan kurikulum 2013 pada kelas VII dan VIII. Sedangkan, siswa kelas IX masih menggunakan kurikulum KTSP. Hal tersebut membuat beberapa guru mengalami kendala di antaranya dalam menguasai dan memahami tentang teks cerita fantasi secara keseluruhan serta cara penerapannya di kelas. Dengan adanya kompetensi dasar yang menuntut siswa untuk mengidentifikasi cerita fantasi maka peneliti merasa perlu untuk meneliti siswa dan mengukur kemampuan siswa dalam mengidentifikasi unsur pembangun cerita fantasi. Mengingat keterbatasan peneliti pada penelitian kemampuan mengidentifikasi unsur pembangun cerita fantasi siswa kelas VII SMPN6 Kota Bengkulu, maka aspek penelitian ini dibatasi dengan menilai kemampuan mengidentifikasi unsur pembangun cerita fantasi yaitu tema, latar, alur dan penokohan. Penelitian ini dirancang 
untuk menghasilkan pembelajaran yang diharapkan dapat mempermudah dalam mengidentifikasi unsur pembangun cerita fantasi dimana pembelajaran teks pada tingkat sekolah menengah pertama terdapat berbagai macam teks diantaranya teks narasi yang berbentuk cerita fantasi.

Teks merupakan ujaran lisan atau tulis bermakna yang berfungsi untuk mengekspresikan gagasan (Priyani, 2014:65). Manusia, binatang, alam atau peristiwa yang dituturkan dapat dilihat pembaca dalam imajinasinya . teks fiksi berarti teks yang merupakan khayalan, teks yang bersifat imajinatif (Kosasih (2014:313). Forster (Nurgiyantoro, 2010:91) mengartikan cerita sebagai sebuah narasi berbagai kejadian yang sengaja disusun berdasarkan urutan waktu. Seperti halnya Forster, Kenny mengartikan cerita sebagai sebuah peristiwa-peristiwa yang terjadi berdasarkan urutan waktu yang disajikan dalam sebuah karya fiksi. Cerita merupakan deretan peristiwa yang terjadi sesuai dengan urutan waktu dalam sebuah karya fiksi. Cerita fantasi adalah cerita yang menampilkan tokoh, alur, atau tema yang derajat kebenarannya diragukan, baik menyangkut (hampir) seluruhan maupun hanya sebagian cerita (Nurgiyantoro 2013:113). Menurut Zulela (2012:47) menyatakan cerita fantasi adalah cerita yang dikembangkan dengan menghadirkan sebuah dunia lain di samping dunia realitas. Cerita fantasi adalah cerita yang menampilkan tokoh, alur, karakter dan lainnya yang kebenarannya diragukan, baik seluruh cerita maupun hanya sebagian cerita.

Aspek Kemampuan Mengidentifikasi Unsur Pembangun Cerita Fantasi

Terdapat yaitu tema, alur, latar dan penokohan. Sayuti (2000:31) menyatakan tema merupakan gagasan sentral, yakni sesuatu yang hendak diperjuangkan dalam dan melalui karya fiksi. Wujud tema dalam fiksi, biasanya berpangkal pada alasan tindak atau motif kokoh. Dalam cerita fantasi juga terdapat alur yang merupakan urutan kejadian yang memperlihatkan tingkah laku tokoh dalam aksinya (Nurgiyantoro, 2010:68). Penokohan juga menjadi salah satu aspek cerita fantasi, yaitu merupakan cara pengarang dalam menggambarkan dan mengembangkan karakter tokoh-tokoh dalam cerita (Nurgiyantoro, 2013:74). Penentu suksesnya dalam mengidentifikasi unsur pembangun cerita fantasi tidak terlepas dari aspek latar yang menjadikan jalan cerita lebih tepat, yaitu latar adalah tempat kejadian, latar waktu dan latar suasana saat kisah terjadi (Nurgiyantoro, 2013:74). Tujuan artikel ini untuk mengetahui kemampuan mengidentifikasi unsur pembangun teks cerita fantasi siswa kelas VII SMPN 6 Kota Bengkulu. Rumusan masalah dalam penelitian ini bagaimana kemampuan mengidentifikasi unsur pembangun cerita fantasi siswa kelas VII SMPN 6 Kota Bengkulu? Penelitian ini juga memiliki manfaat, yaitu manfaat teoritis dan manfaat praktis.

\section{METODE}

Metode yang digunakan dalam penelitian ini adalah metode deskriptif dengan pendekatan kuantitatif. Pendekatan ini menekankan pada prosedur yang ketat dalam menentukan variabel-variabel penelitiannya. Tujuan dari pendekatan kuantitatif ini untuk mengembangkan ilmu pengetahuan yang tertuju pada objek penelitian dengan menggunakan data statistik pada kemampuan mengidentifikasi unsur pembangun cerita fantasi siswa kelas VII SMPN 6 Kota Bengkulu. Dalam penelitian ini, teknik pengumpulan data menggunakan teknik tes menulis yang dilakukan pada siswa kelas VII. 
Populasi dalam penelitian ini adalah siswa kelas VII SMPN 6 Kota Bengkulu tahun ajaran $2019 / 2020$.

Tabel 1. Populasi Siswa Kelas VII SMPN 6 Kota Bengkulu

\begin{tabular}{ccc}
\hline No & Kelas & Jumlah Siswa \\
\hline 1. & VII A & 21 \\
\hline 2. & VII B & 19 \\
\hline 3. & VII C & 34 \\
\hline 4. & VII D & 33 \\
\hline 5. & VII E & 23 \\
\hline 6. & VII F & 24 \\
\hline & Jumlah & 154 \\
\hline
\end{tabular}

Sumber data : Tata Usaha SMP Negeri 6 Kota Bengkulu

Sampel dalam penelitian ini siswa kelas VII -E Dan VII-F menggunakan teknik purposive sampling. Teknik pengumpulan data dalam penelitian ini menggunakan teknik tes tertulis tipe uraian dengan dua judul teks cerita fantasi yang berbeda (Cinderella) dan (Legenda Bulan Jelita). Dalam penelitian ini teknik analisis data menggunakan persentase rumus

Langkah-langkah menganalisis dilakukan dengan teknik sebagai berikut:

a. Memberikan penilaian pada hasil tes kemampuan mengidentifikasi teks cerita fantasi siswa kelas yang telah ditentukan.

b. Penilaian dilakukan oleh dua orang yaitu peneliti dan guru Bahasa Indonesia yang mengajar di kelas

c. Menggabungkan skor penilaian dari dua orang penilai, yakni peneliti dan guru Bahasa Indonesia yang mengajar di kelas.

d. Mencari nilai rata-rata dari hasil penilaian kemampuan mengidentifikasi teks cerita fantasi.

$\mathrm{M}=\frac{\sum X}{N}$

Keterangan :

$\mathbf{M}$ : nilai rata-rata yang dicari dalam persen

$\underline{\Sigma X}$ :Jumlah skor sampel

$\mathbf{N}$ : Jumlah persentase tes

e. Menentukan kualifikasi atau mengategorikan kemampuan siswa dalam mengidentifikasi unsur pembangun teks cerita fantasi dengan interval skala lima sesuai dengan tabel di bawah ini. 
Kemampuan Mengidentifikasi Unsur Pembangun Cerita Fantasi Siswa Kelas VII...

Tabel 2. Rentang Frekuensi Total Skor Kemampuan Mengidentifikasi Cerita Fantasi Siswa

\begin{tabular}{ccc}
\hline No & Nilai & Kategori \\
\hline 1 & $85-100$ & Sangat baik \\
\hline 2 & $70-84$ & Baik \\
\hline 3 & $56-69$ & Cukup \\
\hline 4 & $45-55$ & Kurang \\
\hline 5 & $1-44$ & Sangat Kurang \\
\hline
\end{tabular}

\section{HASIL PENELITIAN DAN PEMBAHASAN}

\section{Hasil}

Hasil penelitian kemampuan mengidentifikasi unsur pembangun cerita fantasi siswa kelas VII SMPN6 Kota Bengkulu terdiri dari empat aspek yaitu tema,alur, latardanpenokohan.

1. Kemampuan Mengidentifikasi Unsur Pembangun Cerita Fantasi Aspek Tema Hasil perhitungan diperoleh nilai rata-rata kemampuan mengidentifikasi unsure pembangun cerita fantasi siswa kelas VII SMPN 6 Kota Bengkulu pada aspek tema sebesar 8,90. Nilai tersebut bila dilihat pada kriteria penilaian aspek tema termasuk dalam kategori baik, karena terletak pada interval nilai 7-8. Dengan demikian, kemampuan mengidentifikasi unsur pembangun cerita fantasi siswa kelas VII SMPN 6 Kota Bengkulu pada aspek tema termasuk dalam kategori baik. 30 siswa termasuk dalam kategori nilai baik, 12 siswa termasuk dalam kategori nilai baik, 5 siswa termasuk dalam kategori cukup, dan tidak ada siswa yang termasuk dalam kategori kurang dan sangat kurang. Hasil perhitungan kemampuan mengidentifikasi unsure pembangun cerita fantasi siswa kelas VII SMPN 6 Kota Bengkulu pada aspek tema pada tabel 5 tersebut, jika dimasukkan dalam interval skala lima untuk perhitungan jumlah frekuensi skornya sebagai berikut.

Tabel 3. Frekuensi Kemampuan Mengidentifikasi Unsur Pembangun Cerita Fantasi pada Aspek Tema

\begin{tabular}{ccc}
\hline Interval Skor Kemampuan & Frekuensi & Keterangan \\
\hline $9-10$ & 30 & Sangat Baik \\
\hline $7-8$ & 12 & Baik \\
\hline $5-6$ & 5 & Cukup \\
\hline $3-4$ & 0 & Kurang \\
\hline $1-2$ & 0 & Sangat Kurang \\
\hline
\end{tabular}

2. Kemampuan Kemampuan Mengidentifikasi Unsur Pembangun Cerita Fantasi Pada Aspek Alur

Hasil perhitungan diperoleh rata-rata kemampuan mengidentifikasi unsur pembangun cerita fantasi siswa kelas VII SMPN 6 Kota Bengkulu. Pada aspek alur sebesar 27,49. Nilai tersebut bila dilihat pada kriteria penilaian aspek alur termasuk dalam kategori baik karena terletak pada interval nilai 25-32. Dengan demikian, 
kemampuan mengidentifikasi unsur pembangun cerita fantasi siswa kelas VII SMPN 6 Kota Bengkulu pada aspek alur termasuk dalam kategori baik. 7 siswa termasuk dalam kategori nilai sangat baik, 24 siswa termasuk dalam kategori nilai baik, 13 siswa termasuk dalam kategori cukup, 3 siswa termasuk dalam kategori kurang, dan tidak ada siswa yang termasuk dalam kategori sangat kurang.

Hasil perhitungan pada kemampuan mengidentifikasi unsur pembangun cerita fantasi siswa kelas VII SMPN 6 Kota Bengkulu. Pada aspek alur tabel 7 tersebut, jika dimasukkan dalam interval skala lima untuk perhitungan jumlah frekuensi skornya sebagai berikut.

Tabel 4. Frekuensi Kemampuan Mengidentifikasi Unsur Pembangun Cerita Fantasi pada Aspek Alur

\begin{tabular}{ccc}
\hline Interval Skor Kemampuan & Frekuensi & Keterangan \\
\hline $33-40$ & 7 & Sangat Baik \\
\hline $25-32$ & 24 & Baik \\
\hline $17-24$ & 13 & Cukup \\
\hline $9-16$ & 3 & Kurang \\
\hline $1-8$ & 0 & Sangat Kurang \\
\hline
\end{tabular}

3. Kemampuan Mengidentifikasi Unsur Pembangun Cerita Fantasi Aspek Latar

Hasil perhitungan diperoleh ini rata-rata kemampuan mengidentifikasi unsur pembangun cerita fantasi siswa kelas VII SMPN 6 Kota Bengkulu pada aspek latar sebesar 16,01. Nilai tersebut bila dilihat pada kriteria penilaian aspek latar termasuk dalam kategori baik, karena terletak pada interval nilai 13-16. Dengan demikian, kemampuan mengidentifikasi unsur pembangun teks cerita fantasi siswa kelas VII SMPN 6 Kota Bengkulu pada aspek latar termasuk dalam kategori baik. Siswa kelas VII SMPN 6 Kota Bengkulu pada aspek latar terbagi atas: 17 siswa termasuk dalam kategori nilai sangat baik, 24 siswa termasuk dalam kategori nilai baik, 4 siswa termasuk dalam kategori cukup, 2 siswa termasuk dalam kategori nilai kurang dan tidak ada siswa yang termasuk dalam kategori sangat kurang.

Hasil perhitungan kemampuan mengidentifikasi unsur pembangun teks cerita fantasi siswa kelas VII SMPN 6 Kota Bengkulupada aspeklatar pada tabel 9 tersebut, jika dimasukkan dalam interval skala lima untuk perhitungan jumlah frekuensi skornya sebagai berikut.

Tabel 5. Frekuensi Kemampuan Mengidentifikasi Unsur Pembangun Cerita Fantasi Pada Aspek Latar

\begin{tabular}{ccc}
\hline Interval Skor Kemampuan & Frekuensi & Keterangan \\
\hline $17-20$ & 17 & Sangat Baik \\
\hline $13-16$ & 24 & Baik \\
\hline $9-12$ & 4 & Cukup \\
\hline $5-8$ & 2 & Kurang \\
\hline $1-4$ & 0 & Sangat Kurang \\
\hline
\end{tabular}


4. Kemampuan Mengidentifikasi Unsur Pembangun Cerita Fantasi Aspek Penokohan Hasil perhitungan diperoleh ini rata-rata kemampuan mengidentifikasi unsur pembangun cerita fantasi siswa kelas VII SMPN 6 Kota Bengkulu pada aspek penokohan sebesar 15,82. Nilai tersebut bila dilihat pada kriteria penilaian aspek penokohan termasuk dalam kategori cukup, karena terletak pada interval nilai 13-18. Dengan demikian, kemampuan mengidentifikasi unsur pembangun cerita fantasi siswa kelas VII SMPN 6 Kota Bengkulu pada aspek penokohan termasuk dalam kategori cukup. Tidak ada siswa termasuk dalam kategori nilai sangat baik, 1 siswa termasuk dalam kategori nilai baik, 36 siswa termasuk dalam kategori cukup, 6 siswa termasuk dalam kategori kurang, dan 4 siswa yang termasuk dalam kategori sangat kurang.

Hasil perhitungan kemampuan mengidentifikasi unsur pembangun cerita fantasi siswa kelas VII SMPN 6 Kota Bengkulu pada aspek penokohan pada tabel 11 tersebut, jika dimasukkan dalam interval skala lima untuk perhitungan jumlah frekuensi skornya sebagai berikut.

Tabel 6. Frekuensi Kemampuan Mengidentifikasi Unsur Pembangun Cerita Fantasi Pada Aspek Penokohan

\begin{tabular}{ccc}
\hline Interval Skor Kemampuan & Frekuensi & Keterangan \\
\hline $25-30$ & 0 & Sangat Baik \\
\hline $19-24$ & 1 & Baik \\
\hline $13-18$ & 36 & Cukup \\
\hline $7-12$ & 6 & Kurang \\
\hline $1-6$ & 4 & Sangat Kurang \\
\hline
\end{tabular}

5. Kemampuan Mengidentifikasi Unsur Pembangun Cerita Fantasi Siswa Kelas VII SMPN 6 Kota Bengkulu.

Hasil perhitungan diperoleh ini rata- kemampuan mengidentifikasi unsur pembangun cerita fantasi siswa kelas VII SMPN 6 Kota Bengkulu sebesar 67,89. Nilai tersebut bila dilihat pada kriteria penilaian termasuk dalam kategori cukup. karena terletak pada interval nilai 56-69. Dengan demikian, kemampuan mengidentifikasi unsur pembangun cerita fantasi siswa kelas VII SMPN 6 Kota Bengkulu termasuk dalam kategori cukup. 2 siswa termasuk dalam kategori nilai sangat baik, 18 siswa termasuk dalam kategori nilai baik, 24 siswa termasuk dalam kategori cukup, 1 siswa termasuk dalam kategori kurang, dan 2 siswa yang termasuk dalam kategori sangat kurang.

Berdasarkan tabel 13, maka hasil kemampuan mengidentifikasi unsur pembangun cerita fantasi siswa kelas VII SMPN 6 Kota Bengkulu jika dimasukkan dalam interval skala lima untuk perhitungan jumlah frekuensi skornya adalah sebagai berikut.

Tabel 7. Interval Tingkat Penguasaan Dengan Persentase untuk Skala Lima

\begin{tabular}{cccc}
\hline No & Skor & Frekuensi Siswa & Kriteria \\
\hline 1 & $85-100$ & 2 & Sangat Baik \\
\hline
\end{tabular}




\begin{tabular}{cccc}
\hline 2 & $70-84$ & 18 & Baik \\
\hline 3 & $56-69$ & 24 & Cukup \\
\hline 4 & $45-55$ & 1 & Kurang \\
\hline 5 & $1-44$ & 2 & Sangat Kurang \\
\hline
\end{tabular}

\section{Pembahasan}

Hasil penelitian kemampuan mengidentifikasi unsur pembangun cerita fantasi siswa kelas VII SMPN 6 Kota Bengkulu yang terdiri dari empat aspek yaitu tema, alur, latar dan penokohan. Memperoleh nilai rata-rata sebesar 67,89 berkategori cukup, dengan artian bahwa dalam mengidentifikasi unsur pembangun cerita fantasi siswa hanya dapat menentukan aspek tema, alur, latar dan penokohan namun masih kurang tepat dalam menunjukkan kutipan yang mendukung dari masing-masing aspek cerita fantasi. Hal ini sesuai dengan teori Samsu Somadayo (2011:10) menjelaskan bahwa kemampuan membaca merupakan suatu proses pemerolehan makna yang secara aktif melibatkan pengetahuan dan pengalaman yang telah dimiliki oleh pembaca serta dihubungkan dengan isi bacaan.

Gambaran tentang kemampuan mengidentifikasi unsur pembangun cerita fantasi siswa kelas VII SMPN 6 Kota Bengkulu dari aspek tema, alur, latar dan penokohan. digunakan teknik deskriptif, yaitu menghitung rata-rata tingkat kemampuan.

Data kemampuan mengidentifikasi unsur pembangun cerita fantasi siswa kelas VII SMPN 6 Kota Bengkulu dari aspek tema dapat dilihat pada tabel 5. Hasil kemampuan subjek penelitian yaitu diperoleh nilai rata-rata sebesar 8,90. Nilai tersebut apabila dilihat pada kriteria penilaian aspek Tema termasuk dalam kategori baik, karena terletak pada interval nilai 7-8. Dengan demikian, kemampuan mengidentifikasi unsur pembangun cerita fantasi siswa kelas VII SMPN 6 Kota Bengkulu dari aspek tema termasuk dalam kategori baik.

Hasil analisis kemampuan mengidentifikasi unsur pembangun cerita fantasi aspek tema baik karena isi tema dan kutipan cerita fantasi lengkap, baik tema tersirat maupun tersurat telah sesuai dengan isi namun kutipan dari identifikasi teks tersebut masih kurang tepat. Mengidentifikasi unsur pembangun cerita fantasi pada aspek tema memperoleh kriteria baik salah satunya adalah (lampiran 022 atas nama Yesica Anggelia Br Sinaga). Hasil ini sesuai dengan teori Sayuti (2000:31) menyatakan tema merupakan gagasan sentral, yakni sesuatu yang hendak diperjuangkan dalam dan melalui karya fiksi. Wujud tema dalam fiksi, biasanya berpangkal pada alasan tindak atau motif kokoh.

Data kemampuan mengidentifikasi unsur pembangun cerita fantasi siswa kelas VII SMPN 6 Kota Bengkulu pada aspek alur dapat dilihat pada tabel 7. Hasil kemampuan subjek penelitian yaitu diperoleh nilai rata-rata sebesar 27,49 Nilai tersebut apabila dilihat pada kriteria penilaian aspek Alur termasuk dalam kategori baik, karena terletak pada interval nilai 25-32. Dengan demikian, kemampuan mengidentifikasi unsur pembangun cerita fantasi siswa kelas VII SMPN 6 Kota Bengkulu pada aspek alur termasuk dalam kategori baik.

Hasil kemampuan mengidentifikasi unsur pembangun cerita fantasi aspek alur adalah baik, karena pengembangan isi cerita sudah tepat namun hanya dapat menunjukkan kutipan yang mendukung saja dari cerita fantasi dan masih tergambar baik. (lampiran 040 atas nama Sinarti). Hasil ini sesuai dengan teori Nurgiyantoro (2010:68) 
menyatakan bahwa alur merupakan urutan kejadian yang memperlihatkan tingkah laku tokoh dalam aksinya.

Data kemampuan mengidentifikasi unsur pembangun cerita fantasi siswa kelas VII SMPN 6 Kota Bengkulu pada aspek latar dapat dilihat pada tabel 9. Hasil kemampuan subjek penelitian yaitu diperoleh nilai rata-rata sebesar 16,01. Nilai tersebut bila dilihat pada kriteria penilaian aspek latar termasuk dalam kategori baik karena terletak pada interval nilai 13-16. Dengan demikian, kemampuan mengidentifikasi unsur pembangun cerita fantasi siswa kelas VII SMPN 6 Kota Bengkulu pada aspek latar termasuk dalam kategori baik.

Hasil kemampuan mengidentifikasi unsur pembangun cerita fantasi siswa pada aspek latar adalah baik, karena siswa dapat menentukan latar sesuai dengan cerita fantasi yang dibaca dengan benar tetapi hanya dapat menunjukkan kutipan yang mendukung dari latar dalam teks cerita fantasi yang benar saja. Kemampuan Mengidentifikasi unsur pembangun cerita fantasi memperoleh kriteria baik salah satunya adalah (lampiran 028 atas nama Jofan Aprian S). Hasil ini sesuai dengan teori Sayuti (2000:126) mengemukakan secara garis besar deskripsi latar fiksi dapat dikategorikan dalam tiga bagian, yakni latar tempat, latar waktu, dan latar sosial. Latar tempat adalah hal yang berkaitan dengan masalah geografis (menyangkut deskripsi tempat suatu peristiwa terjadi), latar waktu berkaitan dengan masalah historis (mengacuh pada saat terjadinya peristiwa, dalam plot secara historis) dan latar sosial berkaitan dengan kehidupan kemasyarakatan (merupakan lukisan status yang menunjukkan hakikat orang atau beberapa orang tokoh dalam masyarakat yang ada di sekelilingnya.

Data kemampuan mengidentifikasi unsur pembangun cerita fantasi siswa kelas VII SMPN 6 Kota Bengkulu pada aspek penokohan dapat dilihat pada tabel 11. Hasil kemampuan subjek penelitian yaitu diperoleh nilai rata-rata sebesar 15,82. Nilai tersebut apabila dilihat pada kriteria penilaian aspek penokohan termasuk dalam kategori cukup, karena terletak pada interval nilai 13-18. Dengan demikian, kemampuan mengidentifikasi unsur pembangun cerita fantasi siswa kelas VII SMPN 6 Kota Bengkulu pada aspek penokohan termasuk dalam kategori cukup.

Hasil kemampuan mengidentifikasi unsur pembangun cerita fantasi siswa pada aspek penokohan adalah cukup, karena sudah dapat menentukan penokohan di dalam cerita fantasi namun masih kurang tepat dalam menunjukkan kutipan yang mendukung dari penokohan cerita fantasi dengan benar saja. Mengidentifikasi unsur pembangun cerita fantasi memperoleh kriteria cukup (lampiran 019 atas nama Rireh Kumala). Hasil ini sesuai dengan teori Nurgiyantoro (2013:74) menyatakan bahwa penokohan merupakan cara pengarang dalam menggambarkan dan mengembangkan karakter tokohtokoh dalam cerita.

Hasil perhitungan yang dianalisis diperoleh nilai rata-rata sebesar 67.89 Nilai tersebut bila dilihat pada kriteria penilaian termasuk dalam kategori cukup, karena terletak pada interval nilai 56-69. Dengan demikian, kemampuan mengidentifikasi unsur pembangun cerita fantasi siswa kelas VII SMPN 6 Kota Bengkulu termasuk termasuk dalam kategori cukup. Dikarenakan siswa hanya mampu menentukan aspek tema, alur, latar dan penokohan namun hanya menunjukkan kutipan yang mendukung saja dari aspek cerita tersebut.

Rincian kemampuan mengidentifikasi siswa yaitu: 2 siswa termasuk dalam kategori nilai sangat baik, 18 siswa termasuk dalam kategori nilai baik, 24 siswa termasuk 
dalam kategori cukup, 1 siswa termasuk dalam kategori kurang, dan 2 siswa yang termasuk dalam kategori sangat kurang.

Model yang digunakan oleh guru dalam pembelajaran mengidentifikasi unsur pembangun cerita fantasi berdasarkan pengamatan yaitu model problem based learning (pembelajaran berbasis masalah), dimana model pembelajaran berbasis masalah ini merupakan suatu konteks bagi peserta didik untuk belajar tentang cara berpikir kritis dan keterampilan pemecahan masalah, serta untuk memperoleh pengetahuan dan konsep yang esensial dari materi pelajaran. Selanjutnya guru juga menggunakan model pembelajaran Discovery Learning (Pembelajaran Penemuan), dimana model pembelajaran penemuan ini merupakan suatu proses pembelajaran yang penyampaian materinya disajikan secara tidak lengkap dan menuntut siswa terlibat secara aktif untuk menemukan sendiri suatu konsep ataupun prinsip yang belum diketahuinya. Disamping model problem based learning (pembelajaran berbasis masalah) dan model pembelajaran Discovery Learning (Pembelajaran Penemuan) guru juga menggunakan model tanya jawab, model diskusi dan model komunikatif. Model pembelajaran tersebut digunakan agar peserta didik lebih aktif dalam pembelajaran berbasis teks berdasarkan kurikulum 2013. Pembelajaran Bahasa Indonesia di kelas VII SMPN 6 Kota Bengkulu dilaksanakan 3 pertemuan (3x40 menit) dalam seminggu, yaitu pada hari Selasa, rabu, dan Sabtu.

\section{PENUTUP}

Berdasarkan hasil penelitian dan pembahasan dapat disimpulkan bahwa kemampuan mengidentifikasi unsur pembangun cerita fantasi siswa kelas VII SMPN 6 Kota Bengkulu tergolong dalam kategori cukup. Hasil mengidentifikasi unsur pembangun cerita fantasi siswa kelas VII SMPN 6 Kota Bengkulu Nilai rata-rata adalah sebesar 67,89 dan berada pada rentang nilai 56-69. Artinya siswa belum baik dalam mengidentifikasi unsur pembangun cerita fantasi. Sehingga perlu memperdalam materi pada cerita fantasi khususnya dalam mengidentifikasi unsur pembangun cerita fantasi aspek tema, alur, latar dan penokohan.

Dilihat dari tiap-tiap aspek dalam penelitian ini, dapat disimpulkan bahwa kemampuan mengidentifikasi unsur pembangun cerita fantasi siswa kelas VII SMPN 6 Kota Bengkulu untuk aspek tema nilai yang diperoleh rata-rata 8,90 dan berada pada kategori baik. Untuk aspek alur yang diperoleh rata-rata 27,49 dan berada pada kategori baik. Aspek latar nilai yang diperoleh rata-rata 16,01 berada pada kategori baik dan Aspek penokohan nilai yang diperoleh rata-rata 15,82 berada pada kategori cukup.

Berdasarkan hasil penelitian yang dilakukan, berikut penulis menyampaikan beberapa saran yang berkaitan dengan penelitian ini.

1. Bagi siswa hendaknya lebih banyak berlatih membaca, sehingga pada saat mengidentifikasi sebuah teks terutama teks cerita fantasi siswa sudah mampu menentukan unsur pembangun cerita fantasi dan menunjukkan kutipannya.

2. Bagi guru memberikan motivasi yang lebih kepada siswa dapat meningkatkan kemampuan belajar siswa, serta memberikan pelajaran yang lebih pada aspek yang mendapatkan kategori cukup.

3. Bagi sekolah, hendaknya menjadi bahan pertimbangan untuk meningkatkan hasil pembelajaran dan mengetahui kemampuan siswa dalam kegiatan membaca serta mengidentifikasi guna meningkatkan motivasi siswa dalam berprestasi. 
Kemampuan Mengidentifikasi Unsur Pembangun Cerita Fantasi Siswa Kelas VII...

\section{DAFTAR PUSTAKA}

Dalman. 2013. Keterampilan Menulis . Jakarta: Rajawali Pers.

Mahsun. 2014. Teks Dalam Pembelajaran Bahasa Indonesia Kurikulum 2013. Jakarta: PT RajaGrafindo Persada.

Nurgiyantoro, Burhan. 2013. Penilaian Pembelajaran Bahasa Berbasis Kompetensi. Yogyakarta: Badan Percetakan Fakultas Ekonomi Universitas Negeri Yogyakarta.

Sayuti, Suminto A. 2000. Kajian Fiksi. Yogyakarta : Gama Media.

Somadayo, Samsu. 2011. Strategi dan Teknik Pembelajaran Membaca. Yogyakarta : Graha Ilmu.

Zulela. 2012. Pembelajaran Bahasa Indonesia. Bandung: PT Remaja Rosdakarya.. 